\title{
Dirençli Epilepsi Tedavisinde Modifiye Atkins Diyeti Uygulaması: Olgu Sunumu
}

\author{
Modified Atkins Diet for the Treatment of Resistant Epilepsy: Case Report
}

\author{
Burcu Kumru' ${ }^{1}$ Alper Dai ${ }^{2}$
}

Geliş tarihi/Received: 13.11.2019 • Kabul tarihi/Accepted: 30.12.2019

\section{ÖZET}

Ketojenik diyet; yüksek miktarda yağ, düşük miktarda karbonhidrat ve orta derecede protein içeren ve enerji kaynağı olarak karbonhidratlar yerine yağların kullanılmasını sağlayan bir diyettir. Yağların yıkılması sonucu ortaya çıkan ketonların beyne yaptığı bir etki mekanizması sayesinde epilepsi nöbetlerin azaldığı düşünülmektedir. Dirençli epilepside modifiye Atkins diyeti (MAD) ilk olarak 2003 yılında John Hopkins Hastanesi’nde geliştirilmiştir. MAD’de karbonhidrat alımı 10-20 g/gün iken enerji, protein, yağ (enerjinin yaklaşık \%75’i) kısıtlaması yoktur ve hastalarda nöbet kontrolünü sağladığını gösteren çalışmalar mevcuttur. MAD, klasik ketojenik diyete göre daha az kısıtlayıcı ve uygulaması daha kolay olduğundan büyük çocuklar ve yetişkinlerde sıklıkla kullanılmaktadır. Bu olgu sunumunda, dirençli epilepsisi olan hastaya uygulanan MAD’nin nöbetler üzerindeki etkinliği incelenmiştir. Diyet tedavisine başladıktan 2 ay sonra nöbetler kesilmiştir ve ciddi bir yan etki görülmemiştir. İlaca yanıt vermeyen dirençli epilepsi hastalarında MAD sağlık profesyonellerinin gözetimi altında uygulanarak etkin bir tedavi seçeneği olarak görülebilir.

Anahtar kelimeler: Dirençli epilepsi, ketojenik diyet, modifiye Atkins diyeti

\begin{abstract}
Ketogenic diet is a high fat, low carbohydrate diet with moderate amounts of protein which leads the body to use fat as the major source of energy instead of carbohydrates. It is suggested that epileptic seizures can be reduced by a mechanism of action of ketones, which are produced by the breakdown of fats, to the brain. Modified Atkins diet (MAD) was first developed in 2003 at John Hopkins Hospital as a treatment option for refractory epilepsy. Carbohydrate intake is limited to 10 to 20 $\mathrm{g} /$ day in MAD, and studies showed that seizure control is achieved although there are no restrictions on calories, protein and fat (approximately 75\% of daily calories). It is frequently used in older children and adolescents as it is less restrictive and easy to use compared with classic ketogenic diet. In this case report, the efficacy of MAD on seizure control in a patient with resistant epilepsy was presented. Two months after initiation of the diet, patient became seizure-free and no serious side effects were observed. In patients with resistant epilepsy who do not respond to medications, MAD applied under the supervision of health professionals may be used as an effective treatment option.
\end{abstract}

Keywords: Resistant epilepsy, ketogenic diet, modified Atkins diet

1. İletişim/Correspondence: Gaziantep Cengiz Gökçek Kadın Doğum ve Çocuk Hastalkları Hastanesi, Beslenme ve Diyet Kliniği, Gaziantep, Türkiye E-posta: burcu-kumru@hotmail.com - $\odot$ https://orcid.org/0000-0001-5760-8218
2. Gaziantep Üniversitesi Tıp Fakültesi, Çocuk Nöroloji Kliniği, Gaziantep, Türkiye (๖) https://orcid.org/0000-0003-0702-8965 


\section{GİRIŞ}

Epilepsi çocuklarda sık görülen nörolojik bir hastalıktır. Çocukluk çağı epilepsi vakalarının çoğu antiepileptik ilaçlara yanıt verse de hastaların üçte birinde ilaca direnç gelişir. Bu hastalarda ketojenik diyet (KD) uygulaması son yıllarda en iyi tedavi seçeneği olarak görülmekle birlikte, bazı metabolik bozukluklarda (glikoz taşıyıcı protein-1 eksikliği, pruvat dehidrogenaz eksikliği vb.) ilk tedavi seçeneği olarak uygulanmaktadır (1). KD başlangıçta açlığın metabolik etkilerini taklit etmek için oluşturulan yüksek yağlı, düşük karbonhidratlı bir diyettir. Etki mekanizmaları açlıktan daha karmaşık olmakla birlikte yüksek yağ ve azaltılmış glukoz alımının, nöbetlerin azalması üzerindeki bağımsız etkilerini gösteren kanıtlar mevcuttur (2). Günümüzde klasik KD, orta zincirli yağ asidi diyeti, düşük glisemik indeks tedavisi ve modifiye Atkins diyeti (MAD) olmak üzere farklı KD tedavileri uygulanmaktadır (2).

MAD besin seçimlerinde klasik KD’ye benzer olarak yüksekyağlı, düşük karbonhidratlı bir diyet tedavisidir (3). Tipik olarak 1:1 ve 1.5:1 ketojenik oran sağlar, ancak belirli bir oran zorunlu değildir ve bazı çocuklarda bu oran 4:1'e kadar çıkabilir (3). MAD'de protein, sıvı ve enerji kısıtlaması yapılmamaktadır. Diyete başlarken, genellikle hastaneye yatış ve açlık fazı gerekmemekle birlikte, öğün planlaması ve öğün miktarları açısından kısitlama bulunmamaktadır. Diyetin karbonhidrat içeriği nöbet kontrolünün sağlanmasına göre 10-20 g/gün olacak şekilde düzenlenebilir. Enerji alımında kısıtlama olmamasından dolayı hasta vücut ağırlık artışı açısından takip edilmelidir. Hastaların nöbetleri günlük olarak kaydedilmeli, haftada 1-2 kez idrar keton düzeylerine bakılmalıdır. MAD’nin klasik KD’ye göre daha az kısıtlı, diyet hesaplaması ve uygulaması daha kolay ayrıca daha lezzetli olması hastaların KD’ye uyumunu arttırmaktadır $(4,5)$. Farklı KD seçenekleri arasında diyetin nöbet kontrolü üzerinde önemli bir fark bulunmamasindan dolayı hastada tercih edilen KD tedavisi KD merkezinin uzmanlığı ile birlikte aile ve çocuğun tercihlerine göre bireyselleştirilmelidir (3). MAD klasik KD’ye göre daha az kısıtlı (enerji ve proteinin alımının serbest birakılması vb.) ve uygulaması daha kolay olduğundan büyük çocuklar ve yetişkinlerde sıklıkla kullanılmaktadır (6).

Dirençli epilepsisi olan çocuklarda yapılan randomize kontrollü bir çalışmada MAD’ın epilepsi üzerinde etkili olduğu görülmüştür (7). Hindistan'da yapılan başka bir randomize kontrollü çalışmada MAD’ın daha basit versiyonu olarak basit ev ölçüleri ve fotoğraflar kullanılmıştır. Bu yöntem düşük okuryazarlık düzeyine sahip ebeveynler için daha yararlı olmuştur (8). MAD, klasik KD kadar etkilidir; ancak 2 yaşından küçük çocukların klasik KD ile nöbet özgürlüğü şansı daha yüksektir (3). Bu olgu sunumunda, dirençli epilepsisi olan hastaya uygulanan MAD'ın nöbetler üzerindeki etkinliği incelenmiştir.

\section{OLGU SUNUMU}

Altı yaş sekiz aylık erkek olgu dirençli epilepsi şikayetiyle başvurmuştur. Olgunun ikili antiepileptik (Depakin $2 \times 250 \mathrm{mg}$ ve Rivotril $3 \times 3$ damla) tedavisine rağmen günde elliye yakın nöbet öyküsü olduğu, ayrıca hastanın destekle ayakta durabildiği, konuşma ve öğrenme güçlüğü olduğu tespit edilmiştir. Hastanede yapılan 24 saatlik elektroensefalografi monitorizasyonunda sağ hemisferde primer olarak başlayıp daha sonra hızlı bir şekilde sekonder generalize olma özelliğinde epileptik bulgular saptanmıştır. Hastanın geçirmiş olduğu nöbet tipi parsiyel kompleks sekonder jeneralize tonik klonik nöbet olarak sınıflandırılmıştır. Hastanın ve ailenin durumu değerlendirilmiş ve hastaya KD başlanması planlanmıştır. Hastanın beslenme öyküsünde yeterli enerji ve protein almadığı görülmüş, ayrıca ailenin diyeti kullanım kolaylığı da göz önüne alınarak KD olarak MAD başlanmasına karar verilmiştir. Böylelikle ailenin diyete uyumunun sağlanmasının yanında çocuğun büyüme ve gelişiminin desteklenmesi hedeflenmiştir.

Diyete başlamadan önce rutin kontroller için hastanın laboratuvar testleri tamamlanmıştır. Diyet öncesinde karaciğer enzim yüksekliği ve ek olarak A vitamin 
eksikliği tespit edilmiş ve destek tedaviye başlanmıştır. Ayrıca hasta folik asit, biotin ve D vitamini takviyesi almaktaymış. Abdomen ultrasonografisinde herhangi bir patolojiye rastlanmamıştır.

Hastanın vücut ağırlığı 16.75 kg olup 1.3’üncü persentilde ve boy uzunluğu ise $114 \mathrm{~cm}$ olup 12.9'uncu persentilde belirlenmiştir. Hastada belirgin büyüme geriliği olduğu görülmüştür. Hastanın beslenme öyküsü alınarak diyet planlaması yapılmıştır. Katı gıdaları zor tükettiği, yarı katı (yoğurt, çorba, ezilmiş ev yemekleri) ve sıvı gıdaları (süt, meyve suyu) daha rahat tüketebildiği belirlenmiştir. Hastadan alınan 24 saatlik besin tüketim kaydında yaklaşık olarak diyet enerjisinin $1200 \mathrm{kkal}$, protein (1.5 g/kg/gün), karbonhidrat ve yağın sırasıyla enerjinin \%8, \%50, \%32'si kadar olduğu görülmüştür. Hastaya günde 6 öğün olacak şekilde yaklaşık $10 \mathrm{~g} /$ gün karbonhidrat, 2.5 $\mathrm{g} / \mathrm{kg} / \mathrm{gün}$ protein ve $1450 \mathrm{kkal} /$ gün enerji içeren MAD başlanmıştır (Tablo 1). Protein kaynağı olarak yoğurt, yumurta ve peynir diyete eklenmiştir. Hastanın sıvı besinleri daha rahat tüketebildiği göz önüne alınarak enerjinin \%48'i, yağın \%50'si mamadan gelecek şekilde günde $100 \mathrm{~g}$ KetoCal 4:1 mama ve omega-3 yağ asidi desteği diyete eklenmiştir. Hastanın örnek menü planı Tablo 2'de verilmiştir. Aileye diyet tarifleri, karbonhidrat-yağ değişimleri, besin etiketleri okuma, günlük nöbet ve haftalık idrar ketonu takibi ile ilgili eğitim verilmiştir.

Tablo 1. Hastaya uygulanan modifiye Atkins diyet tedavisinin içeriği

\begin{tabular}{ll}
\hline Diyet Bileşenleri & Miktar \\
\hline Diyet enerjisi & $1450 \mathrm{kkal} /$ gün \\
Karbonhidrat miktarı & $10 \mathrm{~g} /$ gün \\
Yağ miktarı (enerjinin yaklaşık \%86’sı) & $140 \mathrm{~g} /$ gün (7×10 g'llk değişim ve KetoCal'den $70 \mathrm{~g})$ \\
Protein miktarı (enerjinin yaklaşı \%12’si) & $42 \mathrm{~g} / \mathrm{gün}$ \\
Diyet oranı (yağ: karbonhidrat ve protein) & $2.7: 1$ \\
Sıvı miktarı & $1350 \mathrm{~mL} /$ gün \\
\hline
\end{tabular}

Tablo 2. Bir günlük örnek menü planı

\section{Kahvaltı}

Haşlanmış yumurta

Peynir (tam yağlı)

Tereyağı (2 yağ değişimi)

25 g KetoCal (1 g karbonhidrat değişimi)

Ara

25 g KetoCal (1 g karbonhidrat değişimi)

\section{Öğle yemeği}

Kıymalı sebze çorbası (2.5 g karbonhidrat değişimi)

Zeytinyağı (2 yağ değişimi)

\section{Ara}

$25 \mathrm{~g}$ KetoCal (1 g karbonhidrat değişimi)

\section{Akşam yemeği}

Kıymalı sebze çorbası (2.5 g karbonhidrat değişimi)

Yoğurt (tam yağlı, $1 \mathrm{~g}$ karbonhidrat değişimi)

Zeytinyağı (2 yağ değişimi)

\section{Ara}

25 g KetoCal (1 g karbonhidrat değişimi)

Zeytinyağı (1 yağ değişimi) 
Batman'da yaşayan ailenin diyet kontrolü telefon yoluyla yakından takip edilmiştir. Hasta diyet tedavisine başladıktan 10 gün sonra idrar ketonu +1 olmuş ve nöbet sıklığı 2-3 kez/gün'e düşmüştür. Diyet tedavisine başladıktan 2 ay sonra idrar ketonu +3 olmuş ve nöbetleri durmuştur. Tedavi boyunca hastaya verilen tedaviye uyum sağladığından ve fayda gördüğünden dolayı diyetinde değişiklik yapılmamıştır. Laboratuvar bulguları düzenli olarak takip edilmiş ve herhangi bir bozulma görülmemiştir.

\section{TARTIŞMA}

$\mathrm{KD}$, epilepsi için mevcut en eski tedavilerden biridir. Diyetle birlikte kronik bir ketozis durumu sağlanmaktadır. KD, çocuklarda epilepsi tedavisi için geliştirilen daha yeni antiepileptik ilaçlarla nöbet kontrolündeki etkinliği açısından karşılaştırıldığında yeni antiepileptik ilaçlar kadar etkin olduğu görülmektedir. (9). İkili antiepileptik ilaç tedavisine rağmen nöbet kontrolü sağlanamayan hastalarda vakit kaybetmeden $\mathrm{KD}$ tedavisinin uygulanması göz önünde bulundurulmalıdır. Diyet tedavisinin kesin etkinliğinin değerlendirilmesi için tedavi en az 3 ay süreyle uygulanmalıdır (3). Bu olguda çoklu antiepileptik tedavisine rağmen dirençli epilepsisi olan bir hastada, MAD ile nöbetlerin kontrol altına alındığı görülmüştür.

MAD genellikle iyi tolere edilir (4). MAD, klasik KD’ye kıyasla protein ve enerji kısıtlaması olmaması, hastaneye yatış, açlık ve ayrıntılı hesaplama gerektirmemesi nedeniyle aileler ve hastalar tarafından daha kolay uyum sağlanmaktadır (10). Diyete ve yağ tüketimine uyumun azaldığı dönemlerde, diyete eklenen yüksek yağlı ketojenik bir mamanın da diyetin etkinliğini artırdığı gösterilmiştir (9).

KD’nin metabolik bozukluklar, gastrointestinal semptomlar ve hiperlipidemi gibi yan etkileri görülebilmektedir. KD ile indüklenen hiperlipidemiyi önleme açısından orta zincirli yağ asidi ve zeytinyağ 1 tüketiminin arttırılması, omega-3 veya karnitin takviyesi yapılması, doymuş yağ, kolesterol ve trans yağ asidi alımının azaltılması gibi stratejiler vardır (3). Bunlar açıdan hastaların 1-3 ayda bir klinik kontrole gelmeleri önemlidir (1).

Tedavide MAD’nin dirençli epilepsi üzerine etkinliğini gösteren birçok çalışma bulunmaktadır (10,11). Bir çalışmada hastaların \%65'inde nöbetlerde \%50 azalma, \%35'inde ise nöbetlerde \%90 azalma olduğu görülmüştür (11). Başka bir çalışmada ise hastaların \%55'inde nöbetlerde \%50 azalma görülürken hastaların \%35'inde ise nöbetler tamamen durmuştur (12). Çocuklarda nöbetlerde \%50 azalma sağlandığında diyetin en az 2 yıl sürdürülmesi önerilmektedir (1). KD tedavisinde asıl amaç yüksek düzeyde keton düzeyi sağlamak değil, hastalarda nöbet kontrolünün etkin şekilde sağlanmasıdır. Hastalardaki keton düzeyi her zaman hastaların prognozuyla ilişkili değildir (4).

Bu olguda, hastanın büyüme geriliği ve ailenin diyeti kullanım kolaylığı göz önüne alındığında hastaya MAD başlanmasına karar verilmiştir. Hastanın sıvı gıdaları rahat tüketebilmesi ve ayrıca diyetin nöbet kontrolünde daha etkin olmasının sağlanması açısından ketojenik bir mama (KetoCal, Nutricia) diyete eklenmiştir. Hastada MAD’ye başlandıktan 10 gün sonra günde elliye ulaşan nöbet sıklığında yaklaşık \%90 azalma görülürken, diyete başladıktan 2 ay sonra nöbetler tamamen kesilmiştir. İdrar keton düzeyinde zamanla artış olduğu gözlenirken, diyetin ciddi bir yan etkisi görülmemiştir. Hastanın tedavi öncesi başlanan vitamin takviyelerine ve hiperlipidemiyi önleme açısından diyet tedavisiyle birlikte başlanan omega-3 takviyesine tedavi boyunca devam edilmiştir. Hastanın kullanmış olduğu antiepileptik ilaçlara doz azaltılarak devam edilmiştir (Depakin $2 \times 250 \mathrm{mg}$ ve Rivotril $2 \times 2$ damla). Hastanın diyet tedavisine uyum sorunu yaşamadığı görülmüştür. Tedavinin 6 . ayında olan hasta hala diyet tedavisine devam etmektedir.

Sonuç olarak, ilaca yanıt vermeyen dirençli epilepsi hastalarında MAD tedavisi hastaların nöbetlerini kontrol altına almak için sağlık profesyonellerinin gözetimi altında uygulanarak etkin bir tedavi seçeneği olarak görülebilir. 
Çıkar çatışması - Conflict of interest: Yazarlar çıkar çatışması olmadığını beyan ederler. - The authors declare that they have no conflict of interest.

\section{KAYNAKLAR}

1. Luat AF, Coyle L, Kamat D. The ketogenic diet: A practical guide for pediatricians. Pediatr Ann. 2016;45(12):e44650.

2. deCampo DM, Kossoff EH. Ketogenic dietary therapies for epilepsy and beyond. Curr Opin Clin Nutr Metab Care. 2019;22(4):264-8.

3. Kossoff EH, Zupec-Kania BA, Auvin S, Ballaban-Gil KR, Christina Bergqvist AG, Blackford R, et al. Optimal clinical management of children receiving dietary therapies for epilepsy: Updated recommendations of the International Ketogenic Diet Study Group. Epilepsia Open. 2018;3(2):175-92.

4. Sharma S, Jain P. The Modified Atkins Diet in Refractory Epilepsy. Epilepsy Res Treat. 2014;2014:1-6.

5. Kossoff EH, Dorward JL. The Modified Atkins Diet. Epilepsia. 2008;49(Suppl 8):37-41.

6. Fitzsimmons G, Sewell M. Ketogenic Diets. In: Clinical Paediatric Dietetics. John Wiley \& Sons, Ltd; 2014. p. 354-80.
7. Freeman JM, Vining EPG, Kossoff EH, Pyzik PL, Ye X, Goodman SN. A blinded, crossover study of the efficacy of the ketogenic diet. Epilepsia. 2009;50(2):322-5.

8. Sharma S, Goel S, Jain P, Agarwala A, Aneja S. Evaluation of a simplified modified Atkins diet for use by parents with low levels of literacy in children with refractory epilepsy: A randomized controlled trial. Epilepsy Res. 2016;127:152-9.

9. George R, Salinsky M, Kuzniecky R, Rosenfeld W, Bergen D, Tarver WB, et al. Vagus nerve stimulation for treatment of partial seizures: 3. Long-term followup on first 67 patients exiting a controlled study. First International Vagus Nerve Stimulation Study Group. Epilepsia. 35(3):637-43.

10. Kossoff EH. More fat and fewer seizures: dietary therapies for epilepsy. Lancet Neurol. 2004;3(7):415-20.

11. Kossoff EH, McGrogan JR, Bluml RM, Pillas DJ, Rubenstein JE, Vining EP. A modified Atkins diet is effective for the treatment of intractable pediatric epilepsy. Epilepsia. 2006;47(2):421-4.

12. Chen W, Kossoff EH. Long-Term follow-up of children treated with the modified Atkins diet. J Child Neurol. 2012;27(6):754-8. 